\title{
Lumbricidae Biodiversity at the Sites in Bieszczady Mountains (Poland) After 25 Years
}

\author{
Joanna Kostecka ${ }^{1 *}$, Anna Mazur-Pączka', Grzegorz Pączka', Mariola Garczyńska' \\ 1 Department of Natural Theories of Agriculture and Environmental Education, Faculty of Biology \\ and Agriculture, University of Rzeszow, 1 a Cwiklinskiej St., 35-959 Rzeszow, Poland \\ * Corresponding autor's e-mail: jkosteck@ur.edu.pl
}

\begin{abstract}
Soil degradation is caused by geological, climatic and biological factors, as well as human activities. One kind of degradation involves loss of soil biodiversity as a result of global environmental changes. A study on earthworms was carried out near Ustrzyki Górne in the Bieszczady Mts (Poland), on a monthly basis, in 1986-1987 and 2009-2010 at various sites within the Carpathian beech forests (Fagetum carpaticum). During the years 1986-1987, a total of 13 species of earthworms were found: 6 species on site I, 8 species on site II, and 9 species were recorded within the site III. The highest abundance, i.e. 11 species was found on site IV. The study, which revisited the same locations in 2009-2010, identified only 10 species. In sites I, II and III, 7 earthworm species were found in each, and in site IV -10 species. The authors also investigated the factors endangering the fauna of earthworms in the Bieszczady Mountains, and following the example set by other countries which had made attempts to introduce earthworms into the red lists of the threatened species, it was proposed that such a procedure should be adopted for the endemic species $O$. transpadanus. It was also observed that specimens of $L$. terrestris had penetrated the natural areas of the National Park.
\end{abstract}

Keywords: earthworms, biodiversity, Carpathian beech forest (Fagetum carpaticum)

\section{INTRODUCTION}

Biological diversity is the foundation of ecosystem services. Despite various conservation oriented efforts, biological diversity is decreasing both at the level of species and habitats [Benayas, Bullock 2012]. Because of their specific lifestyle, Lumbricidae play a key role in the soil environment as "the ecosystem engineers". They participate in all the categories of services provided by ecosystems. They are involved in developing soil structure, in circulation of nutrients, primary production, climate regulation, reduction of pollution, and culture-related services; they are a source of nutritious food for animals and, in some cultures, for people [Blouin et al. 2013]. The factors linked with geology, climate and biology, as well as human operations based on excessive exploitation lead to soil environment degradation. In recent years, it has also been pointed out that due to a decreased biological diversity of soil fauna, these resources are also at risk.

The study was designed to compare the biological diversity of Lumbricidae within the subunits of Carpathian beech forests (Fagetum carpaticum), varied in terms of phytosociology, and located in the Western Bieszczady (Poland) after 25 years.

\section{MATERIAL AND METHODS}

The study was carried out in the Western Bieszczady (Poland) near the village of Ustrzyki Górne in 1986-1987 and 2009-2010 in four phytosociologically varied locations within the Carpathian forest (Fagetum carpaticum): I - F. c. festucetosum drymejae, II - F. c. typicum, III F. c. lunarietosum, IV - F. c. allietosum (Fig. 1).

On each occasion, soil temperature and moisture were also measured in the examined locations 


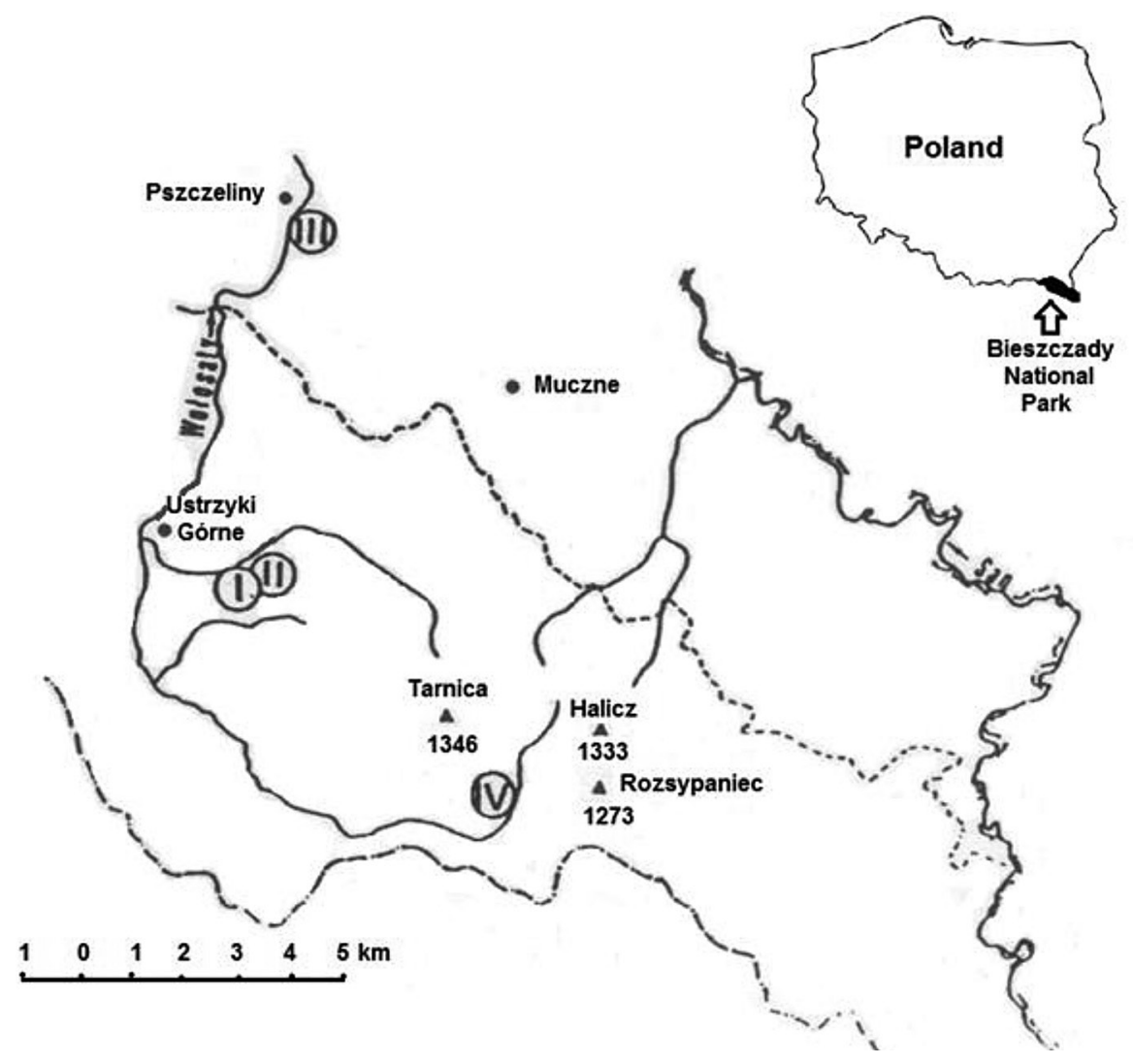

Figure 1. The examined sites within F. carpaticum near Ustrzyki Górne, Poland

at the depth of $0-10 \mathrm{~cm}$ and below this level. Soil moisture was determined with drying method at $105^{\circ} \mathrm{C}$ [Mocek et al. 2000]. For this purpose, three soil samples were collected at the relevant sites, from the layer up to $10 \mathrm{~cm}$ and below $10 \mathrm{~cm}$.

Moreover, at each location, soil samples were collected once in order to examine the $\mathrm{pH}$ at 1 $\mathrm{mol} \cdot \mathrm{dm}^{-3} \mathrm{KCl}$ (potentiometer method), organic carbon (using Tiurin's method), contents of available forms of phosphorus and potassium (EgnerRiehm method) and magnesium (Schachtschabel method) [Mocek et al. 2000] (Table 1).

At each investigated site, eight samples of soil $(0.25 \times 0.25 \mathrm{~m}, 0.25 \mathrm{~m}$ depth $)$ were taken and examined by hand sorting. From the deeper layers, earthworms were expelled using weak formalin solution $(0.4 \%)$ [Zajonc 1970 , EN ISO 23611-1:2006]. The extracted specimens were purified from soil and mucus residues and bathed in water for 15 minutes. They were put down by submerging in $30 \%$ ethyl alcohol, and then transferred to preservation solution (4\% formalin). After 24 hours, formalin was replaced with new solution. The collected specimens stored this way were identified and weighed in the course of a few days.
The obtained data are presented as means \pm standard deviation (SD). The findings were subjected to statistical analyses using STATISTICA ver. 10 software, with Student's t-test.

\section{RESULTS}

During the study of Lumbricidae in 1986-1987 and after 25 years in 2009-2010, the identified earthworms belonging to 3 eco-morphological groups were found (Table 2).

During the years 1986-1987, the total of 13 species of earthworms were found: 6 species at Site I, 8 species at Site II, and 9 species were recorded within Site III. The highest abundance, i.e. 11 species was found on site IV. The study, which revisited the same locations in 2009-2010, identified only 11 species (Table 2). Sites I, II and III, each, were found with 7 earthworm species were found in each, and in site IV - with 10 species.

In 1986-1987 the number of earthworms identified at Site I amounted to $19 \pm 9$ ind. $\cdot \mathrm{m}^{-2}$, at Site II there were $147 \pm 52$ ind. $\mathrm{m}^{-2}$, Site III was found with $140 \pm 63$ ind. $\cdot \mathrm{m}^{-2}$ and Site IV with 110 
Table 1. Characteristics of Lumbricidae sampling sites, in subunits of Fagetum carpathicum near the village of Ustrzyki Górne

\begin{tabular}{|c|c|c|c|c|c|}
\hline \multirow{2}{*}{ Site } & \multirow{2}{*}{ Location } & \multirow{2}{*}{$\begin{array}{c}\text { Altitude } \\
\text { m.a.s.l. [m] }\end{array}$} & \multirow{2}{*}{ Soil type } & \multicolumn{2}{|c|}{ Soil properties } \\
\hline & & & & 1986-1987 & 2009-2010 \\
\hline $\begin{array}{c}\text { F. c. } \\
\text { festucetosum } \\
\text { drymejae }\end{array}$ & $\begin{array}{l}\text { N 4905'52,5" } \\
\text { E } 022^{\circ} 40^{\prime} 17,3^{\prime \prime}\end{array}$ & 740 & $\begin{array}{c}\text { podzolic typical, } \\
\text { slightly sandy } \\
\text { clay, skeletal }\end{array}$ & $\begin{array}{l}\text { mean soil temperature: } \\
(0-10 \mathrm{~cm}) 8.9 \pm 3.6{ }^{\circ} \mathrm{C} \\
(10-20 \mathrm{~cm}) 8.7 \pm 3.4{ }^{\circ} \mathrm{C} \\
\text { mean soil moisture: } \\
(0-0.10 \mathrm{~cm}) 36.9 \pm 7.8 \% \\
(10-20 \mathrm{~cm}) 31.3 \pm 4.4 \% \\
\mathrm{pH}(\mathrm{KCl}) 3.3 \\
\mathrm{C} \text { org. } 2.55 \% \\
\mathrm{P} / 100 \mathrm{~g} \mathrm{d.m} .0 .96 \mathrm{mg} \\
\mathrm{K} / 100 \mathrm{~g} \text { d.m. } 2.6 \mathrm{mg} \\
\mathrm{Mg} / 100 \mathrm{~g} \mathrm{~d} . \mathrm{m} .4 .1 \mathrm{mg}\end{array}$ & $\begin{array}{l}\text { mean soil temperature: } \\
(0-10 \mathrm{~cm}) 11.9 \pm 2.8^{\circ} \mathrm{C} \\
(10-20 \mathrm{~cm}) 11.8 \pm 2.7^{\circ} \mathrm{C} \\
\text { mean soil moisture: } \\
(0-0.10 \mathrm{~cm}) 38.8 \pm 5.4 \% \\
(10-20 \mathrm{~cm}) 38.9 \pm 5.5 \% \\
\mathrm{pH}(\mathrm{KCl}) 3.1 \\
\mathrm{C} \text { org. } 2.43 \% \\
\mathrm{P} / 100 \mathrm{~g} \mathrm{~d} . \mathrm{m} .0 .86 \mathrm{mg} \\
\mathrm{K} / 100 \mathrm{~g} \text { d.m. } 2.7 \mathrm{mg} \\
\mathrm{Mg} / 100 \mathrm{~g} \text { d.m. } 3.8 \mathrm{mg}\end{array}$ \\
\hline F. c. typicum & $\begin{array}{l}\text { N 4905'50,2" } \\
\text { E 022 } 42^{\circ} 15,4^{\prime \prime}\end{array}$ & 750 & $\begin{array}{l}\text { brown } \\
\text { eutrophic, } \\
\text { medium loam, } \\
\text { silty }\end{array}$ & $\begin{array}{l}\text { mean soil temperature: } \\
(0-10 \mathrm{~cm}) 8.9 \pm 3.5^{\circ} \mathrm{C} \\
(10-20 \mathrm{~cm}) 8.7 \pm 3.4^{\circ} \mathrm{C} \\
\text { mean soil moisture: } \\
(0-10 \mathrm{~cm}) 35.1 \pm 3.9 \% \\
(10-20 \mathrm{~cm}) 27.4 \pm 3.3 \% \\
\mathrm{pH}(\mathrm{KCl}) 4,1 \\
\mathrm{C} \text { org. } 1.86 \% \\
\mathrm{P} / 100 \mathrm{~g} \mathrm{d.m} .0 .7 \mathrm{mg} \\
\mathrm{K} / 100 \mathrm{~g} \text { d.m. } 1.7 \mathrm{mg} \\
\mathrm{Mg} / 100 \mathrm{~g} \text { d.m. } 8.0 \mathrm{mg}\end{array}$ & $\begin{array}{l}\text { mean soil temperature: } \\
(0-10 \mathrm{~cm}) 11.7 \pm 2.7^{\circ} \mathrm{C} \text {, } \\
(10-20 \mathrm{~cm}) 11.5 \pm 2.4^{\circ} \mathrm{C} \text {; } \\
\text { mean soil moisture: } \\
(0-10 \mathrm{~cm}) 40.6 \pm 7.9 \% \text {, } \\
(10-20 \mathrm{~cm}) 39.4 \pm 6.6 \% \text {; } \\
\mathrm{pH}(\mathrm{KCl}) 4,0 ; \\
\mathrm{C} \text { org. } 2.00 \% \\
\mathrm{P} / 100 \mathrm{~g} \mathrm{~d} . \mathrm{m} .0 .61 \mathrm{mg} ; \\
\mathrm{K} / 100 \mathrm{~g} \text { d.m. } 1.7 \mathrm{mg} ; \\
\mathrm{Mg} / 100 \mathrm{~g} \text { d.m. } 7.6 \mathrm{mg}\end{array}$ \\
\hline $\begin{array}{c}\text { F. c. } \\
\text { Iunarietosum }\end{array}$ & $\begin{array}{l}\text { N 4908'54" } \\
\text { E } 022^{\circ} 41^{\prime} 11^{\prime \prime}\end{array}$ & 650 & $\begin{array}{c}\text { brown } \\
\text { eutrophic, } \\
\text { heavy loam and } \\
\text { ordinary loam, } \\
\text { silty, skeletal }\end{array}$ & $\begin{array}{l}\text { mean soil temperature: } \\
(0-10 \mathrm{~cm}) 9.7 \pm 4.4^{\circ} \mathrm{C} \\
(10-20 \mathrm{~cm}) 9.5 \pm 4.3^{\circ} \mathrm{C} \\
\text { mean soil moisture: } \\
(0-10 \mathrm{~cm}) 34.3 \pm 5.3 \% \\
(10-20 \mathrm{~cm}) 32.2 \pm 8.8 \% \\
\mathrm{pH}(\mathrm{KCl}) 5.0 \\
\mathrm{C} \text { org. } 2.72 \% \\
\mathrm{P} / 100 \mathrm{~g} \mathrm{d.m} .0 .92 \mathrm{mg} \\
\mathrm{K} / 100 \mathrm{~g} \text { d.m. } 16.3 \mathrm{mg} \\
\mathrm{Mg} / 100 \mathrm{~g} \mathrm{~d} . \mathrm{m} .12 .9 \mathrm{mg}\end{array}$ & $\begin{array}{l}\text { mean soil temperature: } \\
(0-10 \mathrm{~cm}) 12.0 \pm 2.8^{\circ} \mathrm{C} \\
(10-20 \mathrm{~cm}) 11.9 \pm 3.2^{\circ} \mathrm{C} \\
\text { mean soil moisture: } \\
(0-10 \mathrm{~cm}) 36.3 \pm 4.9 \% \\
(10-20 \mathrm{~cm}) 36.6 \pm 4.6 \% \\
\mathrm{pH}(\mathrm{KCl}) 5.0 \\
\mathrm{C} \text { org. } 2.43 \% \\
\mathrm{P} / 100 \mathrm{~g} \text { d.m. } 0.92 \mathrm{mg} \\
\mathrm{K} / 100 \mathrm{~g} \text { d.m. } 16.4 \mathrm{mg} \\
\mathrm{Mg} / 100 \mathrm{~g} \text { d.m. } 12.6 \mathrm{mg}\end{array}$ \\
\hline $\begin{array}{c}\text { F.c. } \\
\text { allietosum }\end{array}$ & $\begin{array}{l}\text { N 4903'24,5" } \\
\text { E } 022^{\circ} 45^{\prime} 44,3^{\prime \prime}\end{array}$ & 960 & $\begin{array}{c}\text { alluvial } \\
\text { chernozem, } \\
\text { silty loam, } \\
\text { highly skeletal }\end{array}$ & $\begin{array}{l}\text { mean soil temperature: } \\
(0-10 \mathrm{~cm}) 8.3 \pm 3.6^{\circ} \mathrm{C} \\
(10-20 \mathrm{~cm}) 8.2 \pm 3.6^{\circ} \mathrm{C} \\
\text { mean soil moisture: } \\
(0-10 \mathrm{~cm}) 39.8 \pm 6.7 \% \\
(10-20 \mathrm{~cm}) 33.6 \pm 16.5 \% \\
\mathrm{pH}(\mathrm{KCl}) 4.8 ; \\
\mathrm{C} \text { org. } 4.53 \% \\
\mathrm{P} / 100 \mathrm{~g} \text { d.m. } 1.61 \mathrm{mg} \\
\mathrm{K} / 100 \mathrm{~g} \text { d.m. } 13.3 \mathrm{mg} \\
\mathrm{Mg} / 100 \mathrm{~g} \text { d.m. } 13.9 \mathrm{mg}\end{array}$ & $\begin{array}{l}\text { mean soil temperature: } \\
(0-10 \mathrm{~cm}) 11.1 \pm 3.4{ }^{\circ} \mathrm{C} \\
(10-20 \mathrm{~cm}) 11.1 \pm 3.7^{\circ} \mathrm{C} \\
\text { mean soil moisture: } \\
(0-10 \mathrm{~cm}) 37.8 \pm 4.9 \% \\
(10-20 \mathrm{~cm}) 38.3 \pm 6.0 \% \\
\mathrm{pH}(\mathrm{KCl}) 4.8 \\
\mathrm{C} \text { org. } 4.52 \% \\
\mathrm{P} / 100 \mathrm{~g} \text { d.m. } 1.48 \mathrm{mg} \\
\mathrm{K} / 100 \mathrm{~g} \text { d.m. } 13.4 \mathrm{mg} \\
\mathrm{Mg} / 100 \mathrm{~g} \text { d.m. } 13.4 \mathrm{mg}\end{array}$ \\
\hline
\end{tabular}

\pm 59 ind. $\cdot \mathrm{m}^{-2}$. The study carried out at the same locations in 2009-2010 enabled to identify lower numbers of earthworms: I - $33 \pm 9$ ind. $\cdot \mathrm{m}^{-2}$; II -48 \pm 11 ind. $\cdot \mathrm{m}^{-2}$; at Site III $-42 \pm 9$ ind. $\cdot \mathrm{m}^{-2}$, and at the most fertile site $66 \pm 12$ ind. $\mathrm{m}^{-2}$ (Figure 2 ).

In the $1980 \mathrm{~s}$, the total earthworm biomass measured at Site I amounted to $11.49 \pm 4.24 \mathrm{~g} \cdot \mathrm{m}^{-2}$, Site II was found with $55.56 \pm 25.20 \mathrm{~g} \cdot \mathrm{m}^{-2}$, the total biomass observed at Site III was $88.95 \pm 54.36$ $\mathrm{g} \cdot \mathrm{m}^{-2}$, and Site IV presented with $105.84 \pm 45.76$ $\mathrm{g} \cdot \mathrm{m}^{-2}$ (Fig. 3). The study carried out 25 years later identified the following amounts: at Site I - 17.18 $\pm 4.55 \mathrm{~g} \cdot \mathrm{m}^{-2}$; II - total biomass of $25.88 \pm 6.17$ $\mathrm{g} \cdot \mathrm{m}^{-2}$; at Site III $-56 \pm 4.74 \mathrm{~g} \cdot \mathrm{m}^{-2}$, and at Site IV $-112.55 \pm 28.34 \mathrm{~g} \cdot \mathrm{m}^{-2}$ (Fig. 3).

\section{DISCUSSION}

The research carried out within natural Carpathian beech forests shows that there is a growing anthropogenic impact negatively affecting the biological diversity, including earthworms. A comparison of research findings acquired at present and in the 1980s may suggest a decrease in the diversity of earthworm communities in the course of twenty five years. The reasons for this, despite the statutory operations conducted in that period (the investigated sites I, II and IV are located within the Bieszczady National Park), may include the direct and/or indirect impacts caused by human activity in this area. Due to these, the 
Table 2. Earthworm species identified in 1986-1987 and in 2009-2010 at the sites within F. carpaticum near Ustrzyki Górne, Poland

\begin{tabular}{|c|c|c|c|}
\hline Species of earthworm & & $1986-1987$ & 2009-2010 \\
\hline Dendrodrilus rubidus tenuis (Savigny 1826) & a & + & + \\
\hline Dendrobaena octaedra (Savigny 1826) & a & + & + \\
\hline Lumbricus rubellus (Hoffmeister 1843) & a & + & _- \\
\hline Eisenia lucens (Waga 1885) & & + & + \\
\hline Octolasion lacteum (Oerley 1881) & $\mathrm{b}$ & + & + \\
\hline Aporrectodea rosea rosea (Savigny 1826) & $\mathrm{b}$ & + & + \\
\hline Aporrectodea caliginosa (Savigny 1826) & $\mathrm{b}$ & + & + \\
\hline Dendrobaena alpina alpina (Rosa 1884) & $\mathrm{b}$ & + & + \\
\hline Allolobophora cernosvitoviana (Zicsi 1967) & $\mathrm{b}$ & + & + \\
\hline Allolobophora carpathica (Cognetti 1927) & C & + & + \\
\hline Octolasion transpadanus (Rosa 1884) & $\mathrm{C}$ & + & - \\
\hline Lumbricus terrestris (L. 1758) & C & + & + \\
\hline Fitzingeria platyura montana (Fitzinger 1833) & $\mathrm{c}$ & + & + \\
\hline Number of species & & 13 & 10 \\
\hline
\end{tabular}

$\mathrm{a}$ - epigeic earthworms; $\mathrm{b}$ - endogeic earthworms, $\mathrm{c}$ - anecic earthworms

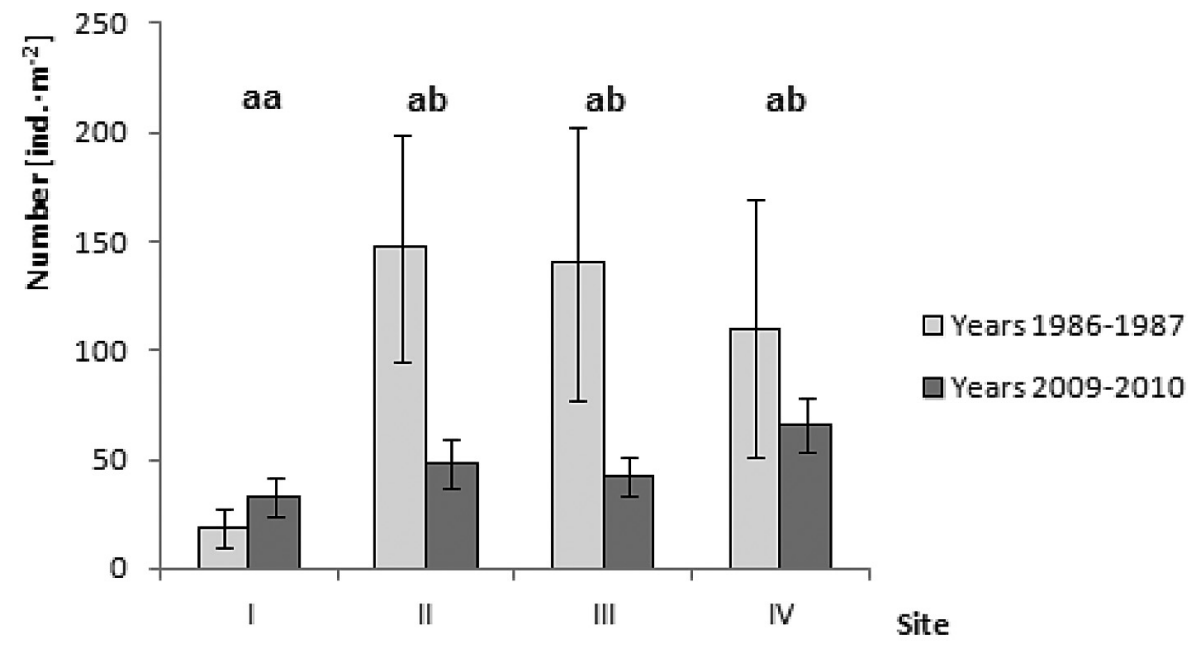

Figure 2. Number [ind. $\cdot \mathrm{m}^{-2}$ ] of earthworms identified in 1986-1987 and in 2009-2010 at the sites within F. carpaticum near Ustrzyki Górne, Poland

aa - statistically insignificant differences $\mathrm{p}>0.05 ; \mathbf{a b}$ - statistically significant differences $\mathrm{p}<0.05$

most vulnerable species are directly in danger of extinction. It seems that one of such species is the large earthworm O. transpadanus (in 1986-1987 the mean number of $2.56 \pm 0.4$ ind. $\cdot \mathrm{m}^{-2}$, the mean biomass $3.12 \pm 0.5 \mathrm{~g} \cdot \mathrm{m}^{-2}$, the mean biomass individual $2.494 \pm 0.529 \mathrm{~g}$ ) which was not found during the study 25 years later.

The presence of $L$. terrestris in Ustrzyki Górne in F. c. allietosum is of particular notice, as the species was not found in the same location in the 1980s [Kostecka, Skoczeń 1993, Kostecka 1998]. It is considered to be a synanthropic species; hence, its presence may be an evidence of anthropogenization of the relevant location. Their increased distribution could be caused by birds or mammals. Yet, it is also rather likely that they could have been spread by the transfer of cocoons e.g. caused by mountain tourism or conservation works carried out in this area by employees of the national park. (e.g. on wheels of machines).

The transformations of the natural environment into anthropogenic areas contribute to a decrease and loss of the original habitats of Lumbricidae. The loss of their natural living grounds as well as pollution of environment, including soil, results in decreased populations and eventually their extinction.

The differences in the number and biomass of earthworm species in the 1980s and at present are presumably linked with the different condi- 


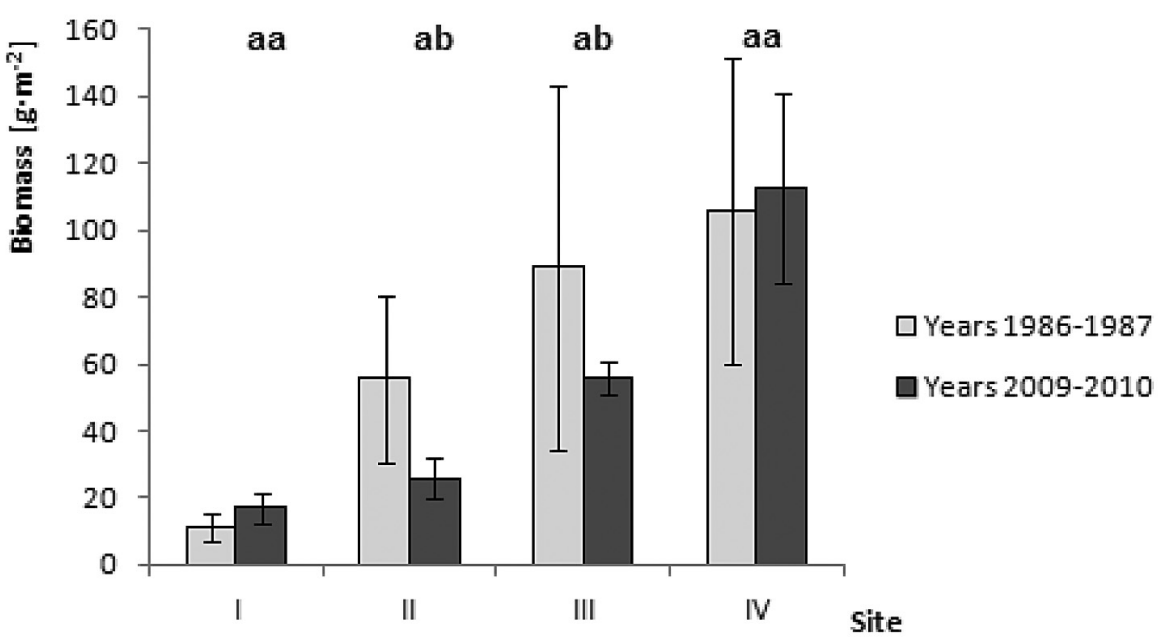

Figure 3. Biomass $\left[\mathrm{g} \cdot \mathrm{m}^{-2}\right]$ of earthworms identified in 1986-1987 and in 2009-2010 at the sites within F. carpaticum near Ustrzyki Górne, Poland

$\mathbf{a a}-$ statistically insignificant differences $\mathrm{p}>0.05 ; \mathbf{a b}-$ statistically significant differences $\mathrm{p}<0.05$

tions, e.g. availability of nutrients in soil, as well as soil temperature and moisture, as these factors largely determine the distribution of earthworms. However, the condition of Lumbricidae colonies living in the relevant areas may also be of importance.

Anthropogenic impacts contribute to increased rates of earthworm species with a wide range of habitats and high adaptation capacities, at the expense of the species with narrow range of distribution. Stenotopic species have lower chances for colonizing new areas. Certain countries conduct monitoring of foreign species which may endanger and drive out the native earthworm species [Gonzalez et al. 2006, Hendrix 2006, Nuutinen, Butt 2009, Plisko 2010].

Increasing attention is paid worldwide to the earthworms protection, e.g. in the Balkan Peninsula a special Red List of endangered species was created for them, defining hazard categories according to International Union for Conservation of Nature and its Resources [Stojanović et al. 2008]. There have also been attempts to develop and update the maps showing their zoogeographical distribution [Carpenter et al. 2012].

In Poland, the classification of Lumbricidae species in compliance with European hazard categories is currently difficult or indeed impossible due to the lack of comprehensive information regarding the status of the specific species. Therefore, it seems that the acquisition of data related to the Lumbricidae populations in the areas which have not been investigated yet, and updating the existing data, is an urgent task.
It also seems that the red list created for the area of the Bieszczady should include the stenotopic species $O$. transpadanus which was not found during the study carried out in 2009-2010.

\section{CONCLUSIONS}

1. The studies described here contribute a lot of significant information. They may provide the basis for comparing the condition of Lumbricidae in the same locations over a long period of time.

2 . The decade of biodiversity (announced for the period of 2011-2020) emphasizes mainly the organisms living above ground; therefore, it is necessary to educate the public about the importance of soil animals in maintaining soil fertility.

\section{REFERENCES}

1. Benayas J.M.R., Bullock J.M. 2012. Restoration of biodiversity and ecosystem services on agricultural land. Ecosystems, 15, 883-899.

2. Blouin M., Hodson M.E., Delgado E.A., Baker G., Brussaard E., Butt K.R., Dai J., Dendooven L., Peres G., Tondoh J.E., Cluzeau D., Brun J.J. 2013. A review of earthworm impact on soil function and ecosystem services. European Journal of Soil Science, 64, 161-182.

3. Carpenter D., Sherlock E., Jones D.T., Chiminoides J., Writer T., Neilson R., Boag B., Keith A.M., Eggleton P. 2012. Mapping of earthworm distribu- 
tion for the British Isles and Eire highlights the under-recording of an ecologically important group. Biodiversity and Conservation, 21, 475-485.

4. EN ISO 23611-1:2006. Soil quality. Sampling of soil invertebrates. Part 1. Hand-sorting and formalin extraction of earthworms. Geneva. Switzerland.

5. González G., Huang Ch.Y., Zou X., Rodríguez C. 2006. Earthworm invasions in the tropics. Biological Invasions, 8, 1247-1256.

6. Hendrix P.F. 2006. Biological invasions belowground: earthworms as invasive species. Biological Invasions, 8, 1201-1204.

7. Kostecka J., Skoczeń S. 1993. Earthworm (Oligochaeta: Lumbricidae) populations in four types of beech wood Fagetum carpaticum in the Bieszczady National Park (south-eastern Poland). Part I. Species composition, diversity, dominancie, frequency and associations. Acta Zoologica Cracoviensia, 36, 1-13.

8. Kostecka J. 1998. Earthworm (Oligochaeta, Lumbricidae) communities in some natural sites in the
Bieszczady Mts. (South-Eastern Poland)". [In:] Soil Zoological Problems in Central Europe. [eds.] V. Pizl, K. Tajovsky. Ceske Budejovice, 93-101.

9. Mocek A., Drzymała S., Maszner P. 2000. Genesis, analysis and classification of soils. University of Agriculture in Poznań (in Polish), 416.

10. Nuutinen V., Butt K.R. 2009. Worms from the cold: lumbricid life stages in boreal clay during frost. Soil Biology and Biochemistry, 41, 1580-1582.

11. Plisko J.D. 2010. Megadrile earthworm taxa introduced to South African soils (Oligochaeta: Acanthodrilidae, Eudrilidae, Glossoscolecidae, Lumbricidae, Megascolecidae, Ocnerodrilidae). African Invertebrates, 51(2), 289-312.

12. Stojanović M., Milutinović T., Karaman S. 2008. Earthworm (Lumbricidae) diversity in the Central Balkans: An evaluation of their conservation status. European Journal of Soil Biology, 44, 57-64.

13. Zajonc I. 1970. Synuzie dazdoviek (Lumbricidae) na lukach karpatskiej oblasti. Ceskoslovenska, Biol. Prace, 16, 1098. 